\title{
NICHE TOURISM IN SOUTH AFRICA: A RENEWED POLICY FOCUS IN THE COVID-19 ENVIRONMENT
}

\author{
Christian M. ROGERSON \\ University of Johannesburg, School of Tourism \& Hospitality, \\ College of Business and Economics, Bunting Road, Johannesburg, South Africa, e-mail: chrismr@uj.ac.za \\ Jayne M. ROGERSON* \\ University of Johannesburg, School of Tourism \& Hospitality, \\ College of Business and Economics, Bunting Road, Johannesburg, South Africa, e-mail: jayner@uj.ac.za
}

\begin{abstract}
Citation: Rogerson, C.M., \& Rogerson, J.M. (2021). NICHE TOURISM IN SOUTH AFRICA: A RENEWED POLICY FOCUS IN THE COVID-19 ENVIRONMENT. GeoJournal of Tourism and Geosites, 39(4spl), 1379-1387. https://doi.org/10.30892/gtg.394spl08-781
\end{abstract}

\begin{abstract}
The COVID-19 pandemic is a catalyst for new patterns of demand and supply for the tourism sector. One consequence is a renewed policy interest in the importance of niche tourism products for destination development. This paper investigates the importance of niche tourism and its (re-) emergence on the policy agenda of tourism stakeholders in South Africa. It is argued that with a resurgence of niche tourism as policy focus there is a need for an extended research agenda on niche tourism in South Africa. The analysis represents a contribution to the changing agendas of tourism scholarship in the global South which have been impacted by the COVID-19 pandemic.
\end{abstract}

Key words: niche tourism, tourism policy, COVID-19, South Africa

\section{INTRODUCTION}

The COVID-19 pandemic has been deemed an unprecedented "supershock" for the global tourism industry (Wassler and Fan, 2021: 1). Tourism geographers have demonstrated that its ramifications have included the collapse of international travel, country lockdowns and the implementation of major restrictions on border crossings which virtually eliminated the tourism economy across the world (Bianchi, 2020; Butler, 2020; Carr, 2020; Cheer, 2020; Gössling et al., 2021; Saarinen and Wall-Reinius, 2021). The mass movement of people, and therefore the phenomenon of 'mass tourism', has been severely curtailed as it imposes great health risks with travellers vulnerable to health hazards (Hall et al., 2020; Fotiadis et al., 2021). The COVID-19 pandemic thus is causing shifts in consumer demands and represents a potential paradigm shift for researching tourist behaviour and decision making (Nair and Sinha, 2020; Rogerson and Rogerson, 2021a). It is reiterated "what was previously taken for granted may not hold anymore in the COVID-19 era" (Kock et al., 2020: 2). New research agendas are emerging (Zenker and Kock, 2020) including for tourism scholars in the Global South (Rogerson and Baum, 2020; Rogerson and Rogerson, 2021b). Uneven geographical impacts are observable in terms of the vulnerability of tourism destinations (Rogerson and Rogerson, 2020, 2021c).

One consequence of the pandemic crisis is that tourism destinations are forced to re-examine their practices and consider 'alternative tourism' which can play an important role in the recovery of the sector and protection of tourism stakeholders (Ioannides and Gyamóthi, 2020). As is made clear by Farsani (2020: 93) within the recent (pre-COVID-19) competitive world of tourism "similarity is the enemy and niche products are a way to escape sameness". Arguably, in a post COVID-19 world, consumers might pivot away further from mass tourism experiences and instead seek out what are styled 'niche tourism' products and experiences. Globally, tourism scholars suggest that in a post-COVID-19 environment the tourism sector is likely to see mobility patterns emerge wherein people start travelling again in smaller cohorts or social bubbles where the risk of catching an infection is relatively lower (Fotiadis et al., 2021). Accordingly, the tourism sector is anticipated to see significant future growth occur in various forms of 'niche travel' and driven primarily by the confidence of travelling in a less risk-prone environment and in smaller groups.

The major policy implications of COVID-19 for changing demand and supply patterns in South Africa's tourism industry are only beginning to be understood and investigated through the pursuit of evidence-based research (Rogerson and Rogerson, 2021a; Rogerson, 2021). South Africa's diverse landscapes and rich natural and cultural heritage can be fertile territory for the development of alternative forms of niche tourism (South African Tourism, 2021). COVID-19 presents an opportunity to explore tourism offerings in which smaller-scale, controlled and operated niche products can be developed to satisfy the shifting demands and needs of consumers. Against this backdrop the aim in this paper is to interrogate the importance of niche tourism and its (re-) emergence on the policy agenda of tourism stakeholders in South Africa. The discussion represents a contribution to the changing directions of tourism geographical scholarship as recently

\footnotetext{
* Corresponding author
} 
identified by Rogerson and Visser (2020) and which have been impacted by the COVID-19 pandemic. In addition, it can be read as strengthening the extant literature about tourism and change in the global South (Saarinen and Rogerson, 2021).

\section{METHODS}

In terms of research methods this paper follows that of several parallel investigations which have appeared recently as a 'rapid response' critical assessment that brings together a variety of available sources and intelligence on COVID19 impacts and policy ramifications (Baum et al., 2020; Bogale et al., 2020; Foo et al., 2020; Korinth and Ranasinghe, 2020; Gössling et al., 2021). The research reported in this paper therefore is anchored on (1) a desk-top survey of international research on niche tourism as sourced through searches of Google Scholar and Scopus; and (2) the collection and scrutiny of policy documentation mined from a range of South African government sources including the Department of Trade and Industry, the Department of Tourism, and South African Tourism.

\section{RESULTS}

The findings of this investigation are organized into the following three sub-sections of material and discussion. These deal with inter alia, (1) definition and conceptual issues; (2) international debates on niche tourism; and, (3) South African policy debates.

\section{Definition and Conceptual Issues}

A starting point for the analysis is that tourism can no longer be considered a singular phenomenon and that 'tourism' is a generic term to cover a broad continuum of travel-related practices. In the view of Papathanassis (2011: 1) as a consequence of the increasing segmentation of the tourism sector as a whole "it would be imprudent to generalize about the development of the tourism sector". Indeed, the tourism industry must be viewed as a fragmented (and fragmenting) industry. Accordingly, macro-perspectives on tourism supply and demand overlook the paradigm shift taking place globally from mass markets to what scholars such as O'Regan $(2014,2017)$ identify as "mass niches".

For Ali-Knight (2010) the origins of literature and conceptual debates around niche tourism can be traced back to the 1980 s with discussions emerging around 'special interest tourism', which is viewed as the predecessor for niche tourism and set the context for the development of niche tourism markets. In a seminal contribution to the literature Novelli (2005) asserts niche tourism can be viewed as breaking down tourism into large homogenous market sectors or macro-niches (such as sports tourism) each of which can be further segmented into sets of micro-niches (such as cycling tourism or ski tourism). Niche tourism products are thus a counterpart to the undifferentiated mass tourism product and refer to specific tourism products focused on meeting the needs of particular market segments. As observed by Connell (2009: 203) during the decade of 2000s a number of "new and significant niches in tourism have steadily appeared and evolved".

Arguably, whilst the concept of 'niche tourism' has entered tourism scholarship debates it remains lacking a clear definition (Macleod, 2003; Robinson and Novelli, 2005). Its origins are rooted in marketing theory with the concept of 'niche marketing' building upon earlier notions of an ecological niche (Richards, 2010). According to Sivadasan (2017: 31) the niche concept "in business enables entrepreneurs to commit resources and products that meet the needs of specific segments". For Marques and Cunha (2010) niche tourism markets are made up of identifiable groups of individuals with similar interests, needs and wants, where specific products can then be tailored to meet the needs of particular market segments, and of varying sizes. For tourists, niche tourism offers a more meaningful set of experiences in the knowledge that their needs and wants are being met (Agarwal et al., 2018). Essentially, it is contended that the suppliers of niche tourism products escape intensified competition in mass markets by "seeking a specific niche which is better suited to them than to their competitors" (Richards, 2010: 79). Although the role and importance of niche tourism has been challenged as a major driving force in tourism growth and destination development there remains a growing body of scholarship that demonstrates niche tourism can offer destinations a valid opportunity to reposition themselves or strengthen their competitiveness (Ali-Knight, 2010; Agarwal et al., 2018; Pforr et al., 2021).

\section{International Research Directions}

Among others Dallen Timothy (2021: 36) argues that from a tourism-specific perspective the development of niche tourism illustrates a trend "towards attractions and destinations that appeal to specialised markets". During the past 20 years there has been a continued expansion of international scholarship as well as the rising tempo of policy debates concerning niche tourism (Weiler and Hall, 1992; Rittichainuwat, 2018; Pforr et al., 2021). Of particular significance is the recent edited volume of contributions by Agarwal et al. (2018) which pinpoints the almost interchangeability of the terminology of "special interest tourism' with that of niche tourism. It is contended that these concepts have "clear overlaps" and "in truth there is little that separates them other than the latter is perhaps more production-centred whilst the former is driven by the consumer's specific interest-based motivations" (Agarwal et al., 2018: 3). The traditional ways of conceptualizing niches have adopted a tourism product supply approach which focuses on an array of products - such as food, film, golf or wine - that might be developed and emerge as a 'portfolio' for particular destinations enabling them to differentiate themselves from competitors. An alternative 'market-led' approach concentrates upon the characteristics of special interest tourists - motivations, behaviour and consumption patterns - that would lead to the attractiveness of certain niches. Illustratively, tourists interested in experiencing alternative cultures might be the target market for food tourism or slow tourism (Agarwal et al., 2018). In a recent contribution Richards (2021: 1) stresses the case for taking a broader view of market niches and highlights that relatively little research attention has been paid "to how niches are identified, develop and are consolidated". 
In several countries tourism policy makers have embraced the promotion of niche tourism, niche tourism products and niche tourism routes (Macleod, 2003; Marques and Cunha, 2010; Farsani, 2020). Among several countries which have instituted policy initiatives for niche tourism development some of the best documented are Romania (Gheorghe, 2014; Gabor and Oltean, 2019), Sri Lanka (Samarathunga and Gamage, 2020) and India (Prabakaran and Panchanatham, 2013; Beigi, 2020; Bandam and Kumar, 2021). In India Malik (2018: 80) records that the national Ministry of Tourism "has started an initiative to recognize, develop and foster niche tourism products". In both India and Sri Lanka much policy interest surrounds niche tourism concepts such as wellness, yoga, tea tourism, Ayurveda and spiritual tourism (Malik, 2018; Samarathunga and Gamage, 2020). According to the World Tourism Organisation and the World Travel and Tourism Council niche tourism is viewed as more valuable for host communities than traditional modes of tourism because of greater spending in destinations (Farsani, 2020). This said, the actual boundaries between mass versus special interest tourism are seen as increasingly "blurry" (Ma et al., 2020: 21) as their behavioural characteristics suggest dividing lines between the two segments which may not be as sharp as often believed.

Arguably, for tourism policy makers and destination managers the concept of niche tourism is compelling as a vehicle for promoting sustainable development and inclusion. Indeed, the niche tourism approach appears to promise "greater opportunities and a tourism that is more sustainable, less damaging and, importantly, more capable of delivering high spending tourists" (Robinson and Novelli, 2005: 1). For tourism policy makers concerned with 'responsible' tourism the attractions of supporting niche tourism are in light of its implied small-scale character and of the discerning and sensitive nature of niche tourists. In addition, niche tourism is touted as having the potential to advance the goals of an inclusive and sustainable economy. In an examination of Portugal Dinis and Krakover (2016) pinpoint the potential contribution of niche products for the development of sustainable tourism in small peripheral localities. Niche product development further can be used to deal with the perennial problems of seasonality for destinations (Malik, 2018). Richards (2021) maintains that a consideration of niche markets is critical for local and regional development futures as increasing competition in the pre-COVID era forces destinations to seek to specialize and differentiate themselves from others. Overall, for successful niche tourism development in any country it is acknowledged there is a need for strategic intervention in the form of policy support which, in turn, demands evidenced-based research in order to inform policy interventions. The COVID-19 pandemic further underlines the importance of developing strategic interventions which are targeted to the requirements of specific niches and informed by an understanding of the changing supply-demand situations of different niches in the post-/continuing environment of COVID-19 (Samarathunga and Gamage, 2020).

Table 1. Research on niche forms of tourism in the urban places of the Global South (Source: Adapted after Rogerson and Rogerson 2021e)

\begin{tabular}{|c|c|}
\hline Form of Niche tourism & Country and Research Examples \\
\hline Adventure & South Africa (McKay, 2013, 2017, 2020) \\
\hline Begging & India (Gowreesunkar et al., 2020) \\
\hline Coastal and marine & South Africa (Rogerson and Rogerson, 2019) \\
\hline Creative & $\begin{array}{l}\text { South Africa (Rogerson, 2006; Booyens and Rogerson, 2019; Drummond and Drummond, 2021); Thailand } \\
\text { (Somnuxpong, 2020) }\end{array}$ \\
\hline Cruise & South Africa (Rink, 2020) \\
\hline Culture/heritage & $\begin{array}{l}\text { Argentina (Schettini and Troncoso, 2011; Kanai, 2014); China (Li and Wu, 2013; Su and Wall, 2015; Wu et al., } \\
\text { 2015; Wang et al., 2020); India (Singh, 1992); Kenya (Sarmento, 2010); Morocco (Lee, 2008); South Africa } \\
\text { (van der Merwe, 2013; van der Merwe and Rogerson, 2013, 2018); Thailand (Trupp and Sunanata, 2017) }\end{array}$ \\
\hline Dark & Argentina (Korstanje and Baker, 2018); Mexico (Speakman, 2019); South Africa (Proos and Hattingh, 2020) \\
\hline Film & Mexico (Adie and Cepeda 2018) \\
\hline Gastronomy & $\begin{array}{l}\text { Bolivia (Cruz et al., 2019); China (Chen and Huang, 2016; Pu et al., 2019); Colombia (Gálvez et al., 2020; } \\
\text { Rodriguez-Gutiérrez et al., 2020); India (Chand et al., 2007; Kaushal and Yadav, 2020); Indonesia (Komaladewi et } \\
\text { al., 2017); Malaysia (Khoo and Badarulzaman, 2014); Peru (Gálvez et al., 2017); South Africa (Naicker and } \\
\text { Rogerson, 2017; Rogerson and Rogerson, 2021d); Thailand (Lunchaprasith, 2017); Vietnam (Avieli, 2013) }\end{array}$ \\
\hline Gay & Mexico (Cantu, 2002; Mendoza, 2013); South Africa (Visser, 2002, 2003; Rink, 2013) \\
\hline Geotourism & Brazil (Del Lama et al., 2015) \\
\hline Graffiti & Colombia (Seok et al., 2020) \\
\hline Halal & South Africa (Bhoola, 2020); Thailand (Uansa-ard and Binprathan, 2018) \\
\hline Medical & Thailand (Lertwannawit and Gulid, 2011; Yin, 2014) \\
\hline Nature & Kenya (Mbatia and Owuor, 2014); South Africa (Burton et al., 2020) \\
\hline Off the beaten track & South Africa (Opfermann, 2021) \\
\hline Sex & Argentina (Jeffrey et al., 2017); Brazil (de Jesus, 2020); Cuba (Wonders and Michalowski, 2001); Peru (Gálvez et al., 2017) \\
\hline Sport & Brazil (Steinbrink, 2013) \\
\hline Volunteer & Mexico (McGehee and Andereck, 2009); Peru (Burrai et al., 2017); South Africa (Rogerson and Slater, 2014) \\
\hline Wedding & South Africa (Rogerson and Wolfaardt, 2015) \\
\hline
\end{tabular}

The sheer diversity of niche tourism offerings can be illustrated by examining the differentiation of niches in the context of urban destinations. Indeed, tourism in urban centres has been a major focus for the development of various forms of niche products. As is shown for the global South a host of different niche tourism products have been used across urban places to strengthen the competitiveness of urban destinations (Rogerson and Rogerson, 2021e). Table 1 provides a snapshot of niche tourism studies for the urban Global South. Three points are observed. First, is the 
remarkable array of niches of tourism that are utilised in the global South for the building of competitive urban destinations. Of interest is that in many cases these innovative niche forms of tourism are pursued outside of major cities and in secondary or intermediate urban places. Second, is that the most popular, as well as the best-documented niches, are the maximisation of local assets for cultural and heritage tourism or food and gastronomy. In many cases these represent the leveraging of particular assets which have been accorded international recognition by UNESCO as either World Heritage Sites or in terms of the designation of Creative Cities. One South African example is the Overstrand which was declared Africa's first UNESCO Creative City of Gastronomy in 2019 (Rogerson and Rogerson, 2021d). Beyond food and gastronomy a burst of other creative tourism offerings is further evidenced in the setting of the urban global South. Finally, in terms of the diversity of niche tourism offerings it is suggested from the weight of existing research that urban destinations in South Africa are, perhaps, the most varied at present. This diversity is, in part, accounted for by understanding the evolution of policy interest that has surrounded niche tourism in South Africa.

\section{Niche Tourism Policy in South Africa}

Policy interest by government in niche tourism in South Africa is not a recent phenomenon. It pre-dates the COVID19 crisis and observed that policy interest concerning niche tourism in South Africa goes back to 2004-5 with the work undertaken by the Tourism Unit within the Department of Trade and Industry (DTI) (Rogerson, 2011). Indeed, prior to the establishment of a separate national Department of Tourism, the activities of the former Department of Environment Affairs and Tourism (DEAT) mainly focused on environmental issues and on poverty reduction associated with government supported tourism projects. From the early 2000s until 2009 therefore the DTI functioned as the lead Ministry in South Africa for national tourism development and planning. By 2005 DTI already had started a process for identifying strategic niche forms of tourism in the economy (Rogerson, 2011).

The promotion of niche tourism markets was considered by the mid-2000s a vehicle for both diversifying the country's tourism products as well as growing volume of tourism. It was stressed that in order to complement the international marketing strategies implemented by South African Tourism the DTI was "keen to understand high growth niche tourism segments" and thus engaged in discussions "with various stakeholders to identify niche tourism segments that should be prioritized for support" (Grant Thornton, 2006: 1). Within broader sectoral planning the DTI considered wide benefits could be obtained from the promotion of niche tourism to enhance tourism's competitiveness. The DTI's analysis was informed by existing international thinking on niche tourism and most especially the works of Novelli (2005) and Robinson and Novelli (2005). The definition of niche tourism as used by South Africa's DTI was that "Niche markets are core groups of people within a target audience who have similar occupational and/of lifestyle characteristics towards which a tourist product may be targeted" (DTI, 2007: 5).

The DTI's approach towards policy development was 'research-led' and began by commissioning research investigations on potential niche markets to inform strategic policy interventions. During 2005 the DTI Tourism Unit isolated the initial three 'niche segments' and funded research studies on business tourism, backpacker tourism and community-based tourism. The business tourism research mainly concentrated on boosting South Africa as a competitive MICE (meetings, incentives, conferences and exhibitions) destination. The objective was to "provide practical recommendations (based on research) as to how the DTI could support the growth of business tourism" (Grant Thornton, 2006: 2). The study on community-based tourism in South Africa centred upon the development of route tourism and implementing themed niche routes as a vehicle for leveraging opportunities for historically disadvantaged enterprises seeking to enter the mainstream tourism economy (ECI Africa, 2006a). The establishment and promotion of tourism routes was viewed as especially important in peripheral spaces to spread tourism benefits to poorer localities and distressed areas with limited economic potential. The third study involved research on backpacker tourism and was wider in scope and provided a set of recommendations for supporting this growing niche market through DTI interventions (ECI Africa, 2006b). In many ways the research on backpacker tourism provided the DTI with a research 'model' for evolving support interventions for niche tourism. Three steps were undertaken. First, was an examination of the market size, value, growth potential and economic impact of the niche sector. Second, package research findings and identify development opportunities to industry stakeholders; and, the third a process of strengthening relevant niche sectors through targeted support measures channelled via relevant (niche) tourism associations. The backpacker tourism investigation disclosed the existence of a vibrant sector that largely had been neglected by government support mechanisms. It revealed opportunities to boost youth tourism and pinpointed the existence of a series of 'barriers to competitiveness' for backpacker tourism that needed to be tackled by policy interventions in South Africa (ECI Africa, 2006b).

Although national government's interest in promoting niche tourism continued to expand, policy uncertainty surrounded the definition of appropriate 'niches'. Arguably, the problems in defining niches were experienced from the outset of DTI's engagement with the concept. The DTI's continued endorsement of niche tourism was manifest in subsequent commitments made under the 2009-2010 Industrial Policy Action Plan which was a set of strategic interventions to lift the growth path of the South African economy (Rogerson, 2014). For the sector of tourism the DTI committed to "the formulation of a Niche Tourism Development Framework" (DTI, 2010a). The purpose of initiating such a framework was to "guide niche tourism development in South Africa and identify high growth and high yield niches to be developed" (DTI, 2010a: 82). Consensus as to the definition of appropriate niches for policy support became ever more complex after the establishment of the separate ministry for tourism. By 2010 a situation existed that two national departments were committed to support niche tourism in South Africa albeit both engaged separately in identifying priority niche segments for support. The two departments selected different niche segments. By September 2010 the core 
responsibility for the initiative for identifying niches effectively had transitioned from the Tourism Unit of the DTI to the new national Department of Tourism (Rogerson, 2011). During 2011 the new Department of Tourism launched its National Tourism Strategy within which a role for niche tourism was isolated (Department of Tourism, 2011a).

The niche tourism development framework had been issued jointly by the DTI and Department of Tourism in 2010 (DTI \& Department of Tourism, 2010). The rationale to conceive, develop and resource niche tourism in South Africa was driven variously by it representing a potentially high value visitor target, its opportunities for encouraging a geographical spread of tourism, addressing seasonality and supporting new market opportunities for small, medium and microenterprises. Niche tourism markets, it was stated were "extremely important to the key objectives of South Africa's tourism agenda" (DTI \& Department of Tourism, 2010: 9). The niche tourism development framework was to chart a pathway for stimulating niche tourism development in the country. By this time, the DTI had completed its investigations on backpacker tourism, business tourism, community-based tourism and avitourism (DTI, 2010b). In addition, it launched plans for work to be commissioned on accessible tourism and educational tourism for financial year 2010-11. The Department of Tourism started its work on niche tourism with research studies on cruise tourism and medical tourism.

Overall, it is evident the years 2010-2011 represented an intense period of commitment to research for support of the niche tourism development framework. The DTI produced in 2010 a landmark investigation on the potential for birding or avitourism in South Africa (DTI, 2010b). This was followed in 2011 by the appearance of market studies commissioned on educational tourism (Department of Tourism, 2011b) and accessible tourism (Department of Tourism, 2011c). The production of these research studies indicate the major policy interest that surrounded niche tourism at this time within national government. Further endorsement for niche product development and support in South Africa came with the National Tourism Sector Strategy (NTSS) which appeared in early 2011 (Department of Tourism, 2011c).

For the period 2010-2020 the NTSS identified niche product development and 'rural tourism' as one of the Department of Tourism's major focal points for policy work (Department of Tourism, 2011d). Niche product development increasingly became aligned with the promotion of 'rural tourism'. The central thrust of what was termed 'rural tourism' promotion would be directed geographically towards the spaces of the Bantustans (the former apartheidestablished Homelands) which were the core 'distressed' regions of South Africa.

During the next five years the priorities of the Department of Tourism became firmly focused on issues around 'transformation' with the consequence that niche tourism appears to have become relegated to the policy side-lines. As Abrahams (2019) points out transformation essentially is focused on shifting the racial complexion of ownership and benefits from tourism development with specific targets for formerly disadvantaged groups (especially Black South Africans) under apartheid. Although transformation initiatives go back to the early 2000 s they gained a strong policy momentum in the decade of 2010-2020. It was argued transformation was "regarded as a national imperative in South Africa to deal with inequalities of the past" and represented even a possible growth stimulant for the tourism sector in pre-COVID-19 times (Abrahams, 2019: 821). Undoubtedly, 'transformation' became the central focus of policy work by the Department of Tourism. Nevertheless, the continued commitment of the Department of Tourism to niche tourism was demonstrated in November 2017 with the revision and updating of the National Tourism Sector Strategy. Niche tourism now became discussed also as contributing to government transformation objectives (Department of Tourism, 2018). By 2018 it could be asserted that the "South African government perceives niche markets as a unique leverage to inclusively develop a destination" (Van Wyk-Jacobs, 2018: 57). The significance of strategic interventions for critical niches in tourism was further evident in a 2020 Economic Survey report on South Africa which was produced by the Organization of Economic Cooperation and Development (Glocker and Haxton, 2020).

This report emphasized that tourism in South Africa "has good potential to support the South African economy and contribute to employment growth post-COVID-19" (Glocker and Haxton, 2020: 3). At the provincial level in South Africa also niche tourism has gained support for integration into tourism development planning as is evidenced by recent findings from Free State (Proos and Hattingh, 2020). The 2021 Tourism Sector Recovery Plan issued by South African Tourism is government's major policy statement in response to re-energising the tourism economy in the COVID-19 environment (South African Tourism, 2021). It recognises re-igniting demand requires a robust marketing strategy, the agility to respond decisively through an uncertain global re-opening phase and responsiveness to changes in consumer preferences that require a focus on intrepid, experiential traveller segments which include niche tourism development. Overall, the pandemic further underlines the importance of developing interventions that are targeted to the requirements of specific niches. As observed by Nel (2021: 50) tourism "on a small scale as seen in niche tourism and special interest tourism has begun to play an ever more vital role in South Africa following the economic decline that occurred due to the COVID-19 virus and associated lockdowns".

\section{CONCLUSION}

In the pre-COVID-19 era it was observed as far back as the early 1990s that fundamental changes were occurring in the market for tourism with the emergence of new patterns of tourist consumption (Weiler and Hall, 1992). A decade later it could be re-iterated that "the development of niche tourism is widely acknowledged as a major trajectory in contemporary tourism" (Robinson and Novelli, 2005: 7). Furthermore, McKercher and Chan (2005: 21) alluded that the special interest tourism market was "thought to be very special". Policy interest has emerged in several countries across the global South in the potential of leveraging opportunities from niche tourism. The example of South Africa shows that niche tourism development has continuously appeared on the agenda of national tourism policy makers since 2000 which makes the country an instructive case study in niche tourism policy. 
The government's policy focus around transformation has been the number one policy priority for the latter part of the 2010 decade. With the acceleration of the COVID-19 pandemic the importance of niche tourism is reinforced for tourism policy and planning in South Africa as consumer demands shift from 'mass attractions' to smaller-scale forms of tourism. Arguably, niche tourism can be an element for tourism COVID-19 recovery planning as well as for leveraging the growth of an inclusive and sustainable tourism in South Africa (Glocker and Haxton, 2020). This underlines the relevance of an extended research agenda to understand international good practice for niche tourism planning as well as the pursuit of research investigations in South Africa on critical niches in order to provide an evidence base for supporting niche tourism. A comprehensive research programme is merited to support the renewal of interest in niche tourism policy development. It should address local knowledge-gaps about the changing supply-demand situations of particular niches during and post COVID-19. At least two sets of policy research work would be useful. First, is research to tackle certain critical knowledge lacuna about niche tourism, best practice policy interventions, and of specific forms of niche tourism in South Africa. Second, is to undertake research which critically examines the challenges for leveraging niche tourism for achieving the Department of Tourism goals for an inclusive and sustainable tourism economy in South Africa and with due recognition to the demand/supply challenges resulting from the uncertain times of COVID-19.

\section{Acknowledgements}

Thanks are due to Arabella Rogerson for editorial inputs and to funding from Department of Tourism. An earlier version of this paper was presented at the 2021 online Conference of the Society of South African Geographers.

\section{REFERENCES}

Abrahams, D. (2019). Transformation of the tourism sector in South Africa: A possible growth stimulant? GeoJournal of Tourism and Geosites, 26 (3), 821-830. DOI 10.30892/gtg.26312-400

Adie, B.A. \& Cepeda, R.G. (2018). Film tourism and cultural performance: Mexico City's day of the dead parade. In E. Kromidha \& S. Deesilatham (Eds.), Inclusive innovation for enhanced local experience in tourism: Workshop proceedings. 33-36, Phuket, Thailand.

Agarwal, S., Busby, G., \& Huang, R. (2018). Special interest tourism: Concepts, contexts and cases. Wallingford: CABI.

Ali-Knight, J. (2010). The role of niche tourism products in destination development. PhD dissertation, Edinburgh Napier University, Edinburgh, Scotland.

Avieli, N. (2013). What is 'local food'?: Dynamic culinary heritage in the world heritage site of Hoi An, Vietnam. Journal of Heritage Tourism, 8 (2-3), 120-132. https://doi.org/10.1080/1743873X.2013.767812

Bandam, R., \& Kumar, J.R. (2021). Tourism service in India: A model for identifying niche tourism products in view of foreign tourists. International Journal of Hospitality \& Tourism Systems, 14 (1), 121-127.

Baum, T., Mooney, S.K.K., Robinson, R.N.S., \& Solnert, D. (2020). COVID-19's impact on the hospitality workforce - new crisis or amplification of the norm. International Journal of Contemporary Hospitality Management, 32 (9), 2813-2829.

Beigi, H. (2020). An evaluation of niche tourism potentials in Ghaleh-Rudkhan tourism target village using activity-based segmentation. Journal of Research and Rural Planning, 9 (2), 49-67. https://dx.doi.org/10.22067/jrrp.v9i2.81067

Bhoola, S. (2020). Halal food tourism: Perceptions of relevance and viability for South African destinations. African Journal of Hospitality, Tourism and Leisure, 9 (3), 288-301. https://doi.org/10.46222/ajhtl.19770720-19

Bianchi, R. (2020). COVID-19 and the potential for a radical transformation of tourism? ATLAS Tourism and Leisure Review, 2020-2, 80-86.

Bogale, M., Kelkay, S., \& Mengesha, W. (2020). COVID-19 pandemic and tourism sector in Ethiopia. Horn of Africa Journal of Business and Economics (Special Issue 1, June), 1-9.

Booyens, I., \& Rogerson, C.M. (2019). Recreating slum tourism: Perspectives from South Africa. Urbani izziv, 30 (Supplement), $52-63$.

Burrai, E., Mostafanezhad, M., \& Hannam, K. (2017). Moral assemblages of volunteer tourism development in Cusco, Peru. Tourism Geographies, 19 (3), 362-377. https://doi.org/10.1080/14616688.2016.1236145

Burton, C., Rogerson, J.M., \& Rogerson, C.M. (2020). The making of a 'big 5' game reserve as an urban tourism destination: Dinokeng, South Africa. African Journal of Hospitality, Tourism and Leisure, 9 (6), 892-911.

Butler, R. (2020). Tourism - resilient but vulnerable as "the times they are a changing" in the "new normality". Worldwide Hospitality and Tourism Themes, 12 (6), 663-670. https://doi.org/10.1108/WHATT-07-2020-0063

Cantu, L. (2002). De ambiente: Queer tourism and the shifting boundaries of Mexican male sexualities. GLQ: A Journal of Lesbian and Gay Studies, 8 (1-2), 139-166.

Carr, A. (2020). AOTEAROA: A post-COVID nature-centric world. ATLAS Tourism and Leisure Review, 2020-2, 30-36.

Chand, M., Dahiya, A., \& Patil, L.S. (2007). Gastronomy tourism - a tool for promoting Jharkhand as a tourist destination. Atna Journal of Tourism Studies, 2, 88-100. https://doi.org/10.12727/ajts.2.8

Cheer, J. (2020). Human flourishing, tourism transformation and COVID-19: A conceptual touchstone. Tourism Geographies, 22 (3), 514-524. https://doi.org/10.1080/14616688.2020.1765016

Chen, Q., \& Huang, R. (2016). Understanding the importance of food tourism in Chongqing, China. Journal of Vacation Marketing, 22 (1), 42-54. https://doi.org/10.1177\%2F1356766715589427

Connell, J. (2009). Birdwatching, twitching and tourism: Towards an Australian perspective. Australian Geographer, 40 (2), $203-217$. https://doi.org/10.1080/00049180902964942

Cruz, F.G.S., Tito, J.C., Perez-Galvez, J.C., \& Medina-Viruel, M.J. (2019). Gastronomic experiences of foreign tourists in developing countries: The case in the city of Oruro (Bolivia). Heliyon, 5 (7), e02011. https://doi.org/10.1016/j.heliyon.2019.e02011

de Jesus, D.S.V. (2020). The boys of summer: Gay sex tourism in Rio de Janeiro. Advances in Anthropology, 10, $125-146$. https://doi.org/10.4236/aa.2020.102008

Del Lama, E.A., de la Corte Bacci, D., Martins, L., Gracia, M.D.G.M., \& Dehira, L.K. (2015). Urban geotourism and the old centre of São Paulo City, Brazil. Geoheritage, 7, 147-164. https://doi.org/10.1007/s12371-014-0119-7

Dinis, A., \& Krakover, S. (2016). Niche tourism in small peripheral towns; The case of Jewish heritage in Belmonte, Portugal. Tourism Planning \& Development, 12 (3), 310-332. https://doi.org/10.1080/21568316.2015.1114014 
Drummond, J., \& Drummond, F. (2021). The historical evolution of the cultural and creative economy of Mahikeng, South Africa: Implications for contemporary policy. In R. Comunian, B.J. Hracs \& L. England (Eds.). Developing creative economies in Africa: Policies and practice, 97-112. London: Routledge.

Farsani, N.T. (2020). Promoting ghetto niche tourism in Isfahan, Iran. Journal of Heritage Tourism, 15 (1), 93-102. https://doi.org/10.1080/1743873X.2019.1593990

Foo, L.P., Chin, M.Y., Tan, K.L \& Phuah, K.T. (2020). The impact of COVID-19 on tourism industry in Malaysia. Current Issues in Tourism https://doi.org/10.1080/13683500.2020.1777951

Fotiadis, A.K., Woodside, A.G., Del Chiappa, G., Seraphin, H., \& Hansen, H.O. (2021). Novel coronavirus and tourism: Coping, recovery and regeneration issues. Tourism Recreation Research, 46 (2), 144-147. https://doi.org/10.1080/02508281.2021.1919422

Gabor, M.Z., \& Oltean, F.D. (2019). Babymoon tourism between emotional well-being service for medical tourism and niche tourism: Development and awareness on Romanian educated women. Tourism Management, 70, 170-175. https://doi.org/10.1016/j.tourman.2018.08.006

Gálvez, J.C.P., López-Guzmán, T., Buiza, F.C., \& Medina-Viruel, M.J. (2017). Gastronomy as an element of attraction in a tourist destination: The case of Lima, Peru. Journal of Ethnic Foods, 4 (4), 254-261. https://doi.org/10.1016/j.jef.2017.11.002

Gálvez, J.C.P., Gallo, L.S.P., Medina-Viruel, M.J., \& López-Guzman, T. (2020). Segmentation of tourists that visit the city of Popayán (Colombia) according to their interest in gastronomy. Journal of Culinary Science \& Technology. https://doi.org/10.1080/15428052.2020.1738298

Gheorghe, O.R. (2014). Types of niche tourism in Romania. Cactus Tourism Journal, 10 (2), 25-29.

Glocker, D., \& Haxton, P. (2020). Leveraging tourism development for sustainable and inclusive growth in South Africa. Paris: OECD Report No. ECO/WKP 29.

Gössling, S., Scott, D., \& Hall, C.M. (2021). Pandemics, tourism and global change: A rapid assessment of COVID-19. Journal of Sustainable Tourism, 29 (1), 1-20. https://doi.org/10.1080/09669582.2020.1758708

Gowreesunkar, V.G., Seraphin, H., \& Nazimuddin, M. (2020). Beggarism and black market tourism - a case study of the city of Chaar Minaar in Hyderabad (India). International Journal of Tourism Cities. https://doi.org/10.1108/IJTC-12-2019-0210

Hall, C.M., Scott, D., \& Gössling, S. (2020). Pandemics, transformations and tourism: Be careful what you wish for. Tourism Geographies, 22 (3), 577-598. https://doi.org/10.1080/14616688.2020.1759131

Ioannides, D., \& Gyamóthi, S. (2020). The COVID-19 crisis as an opportunity for escaping the unsustainable global tourism path. Tourism Geographies, 22 (3), 624-632. https://doi.org/10.1080/14616688.2020.1763445

Jeffrey, H.L., Vorobjovas-Pinta, O., \& Sposato, M. (2017). It takes two to tango: Straight-friendly Buenos Aires. In Critical Tourism Studies VII Conference: Book of Abstracts, $25-29$ June, (p. 77) Palma de Mallorca, Spain.

Kanai, M. (2014). Buenos Aires, capital of tango: Tourism, redevelopment and the cultural politics of neoliberal urbanism. Urban Geography, 35 (8), 1111-1117. https://doi.org/10.1080/02723638.2014.957112

Kaushal, V., \& Yadav, R. (2020). Understanding customer experience of culinary tourism through food tours of Delhi. International Journal of Tourism Cities. https://doi.org/10.1108/IJTC-08-2019-0135

Khoo, S.L., \& Badarulzaman, N. (2014). Factors determining George Town as a city of gastronomy. Tourism Planning \& Development, 11 (4), 371-386. https://doi.org/10.1080/21568316.2013.874365

Kock, F., Nǿrfelt, A., Josiassen, A., Assaf, A.G., \& Tsionas, M.G. (2020). Understanding the COVID-19 psyche: The evolutionary tourism paradigm. Annals of Tourism Research, 85, 103053. https://doi.org/10.1016/j.annals.2020.103053

Komaladewi, R., Mulyana, A., \& Jatnika, D. (2017). The representation of culinary experience as the future of Indonesian tourism cases in Bandung city, West Java. International Journal of Business and Economic Affairs, 2 (5), 268-275. https://doi.org/10.24088/IJBEA-2017-25001

Korinth, B., \& Ranasinghe, R. (2020). COVID-19 pandemic's impact on tourism in Poland in March 2020. GeoJournal of Tourism and Geosites, 31 (3), 987-990.

Korstanje, M.E., \& Baker, D. (2018). Politics of dark tourism: The case of Cromanon and ESMA, Buenos Aires, Argentina. In P. Stone, R. Hartmann, T., Seaton, R., Sharpley \& L. White (Eds.), Handbook of dark tourism, 533-552, Basingstoke, Palgrave Macmillan.

Lee, J. (2008). Riad fever: Heritage tourism, urban renewal and the medina property boom in old cities of Morocco. E Review of Tourism Research, 6, 66-78.

Lertwannawit, A., \& Gulid, N. (2011). International tourists service quality perception and behavioral loyalty toward medical tourism in Bangkok metropolitan area. Journal of Applied Business Research, 27 (6), 1-12. https://doi.org/10.19030/jabr.v27i6.6460

Li, M., \& Wu, B. (2013). Urban tourism in China. London: Routledge.

Lunchaprasith, T. (2017). Gastronomic experience as a community development driver: The study of Amphawa Floating Market as communitybased culinary tourism destination. Asian Journal of Tourism Research, 2 (2), 84-116. https://doi.org/10.12982 AJTR.2017.00011

Ma, S., Kirilenko, A.P., \& Stepchenkova, S. (2020). Special interest tourism is not so special after all: Big data evidence from the 2017 Great American Solar Eclipse. Tourism Management, 77, 104021. https://doi.org/10.1016/j.tourman.2019.104021

Macleod, D.V. (2003). Niche tourism in question: Interdisciplinary perspectives on problems and possibilities. Glasgow: Crichton.

Malik, G. (2018). Niche tourism: A solution to seasonality. Journal of Management Research and Analysis, (Ed.), 5 (2), 80-93.

Marques, L., \& Cunha, C. (2010). Literary rural tourism entrepreneurship: Case-study evidence from northern Portugal. In ATLAS (comp.), Mass tourism vs niche tourism: Cyprus 2010 ATLAS conference 3-5 November Limassol - extended abstracts, 58-63, Arnhem, ATLAS.

Mbatia, T.W., \& Owuor, S. (2014). Prospects for urban eco-tourism in Nairobi, Kenya: Experiences from the Karura forest reserve. African Journal of Sustainable Development, 4 (3), 184-198.

McGehee, N.G., \& Andereck, K. (2009). Volunteer tourism and the "voluntoured": The case of Tijuana, Mexico. Journal of Sustainable Tourism, 17 (1), 39-51. https://doi.org/10.1080/09669580802159693

McKay, T. (2013). Leaping into urban adventure: Orlando bungee, Soweto, South Africa. African Journal for Physical, Health Education, Recreation and Dance, 18 (Supplement), 55-71.

McKay, T. (2017). The South African adventure tourism economy: An urban phenomenon. Bulletin of Geography: Socio-Economic Series, 37, 63-76.

McKay, T. (2020). Locating great white shark tourism in Gansbaai, South Africa within the global shark tourism economy, 283-297, In J.M. Rogerson \& G. Visser (eds.), New directions in South African tourism geographies. Cham, Switzerland: Springer, $203-226$.

McKercher, B., \& Chan, A. (2005). How special is special interest tourism? Journal of Travel Research, 44, 21-31. https://doi.org/10.1177\%2F0047287505276588

Mendoza, C. (2013). Beyond sex tourism: Gay tourists and male sex workers in Puerto Vallarta (Western Mexico). International Journal of Tourism Research, 15 (2), 122-137. https://doi.org/10.1002/jtr.1865 
Naicker, M.S., \& Rogerson, J.M. (2017). Urban food markets; A new leisure phenomenon in South Africa. African Journal of Hospitality, Tourism and Leisure, 6 (3), 1-17.

Nair, B.B., \& Sinha, S. (2020). COVID-19 and future travel decisions: How do the destination-choice based motivators redefine tourist's choices. Enlightening Tourism: A Pathmaking Journal, 10 (2), 306-322.

Nel, H. (2021). From pharology to tourism: Shining a light on South African lighthouses. Masters thesis (Heritage and Cultural Tourism), University of Pretoria, Pretoria.

Novelli, M. (2005). Niche tourism: Contemporary issues, trends and case studies. London: Routledge.

Opfermann, L.S. (2021). Walking in Jozi: Guided tours, insecurity and urban regeneration in inner city Johannesburg. Global Policy, 12, 41-52. https://doi.org/10.1111/1758-5899.12809

O’Regan, M. (2014). Fragmenting tourism: Niche tourists. In S. McCable (Ed.), The Routledge handbook of tourism marketing, London: Routledge.

O'Regan, M. (2017). Niche tourism. In L.L. Lowry (Eds.), The SAGE international encyclopedia of travel and tourism, 901-904, Thousand Oaks, Sage.

Papathanassis, A. (2011). The long tail of tourism: Holiday niches and their impact on mainstream tourism. (Ed.), Wiesbaden, Gabler.

Pforr, C., Dowling, R., \& Volgger, M. (2021). Consumer tribes in tourism: Contemporary perspectives on special-interest tourism, (Eds.) Singapore, Springer Nature.

Prabakaran, N., \& Panchanatham, N. (2013). Niche tourism products of India. Abasyn Journal of Social Sciences, 6 (1).

Proos, E., \& Hattingh, J. (2020). Dark tourism: Growth potential of niche tourism in the Free State Province, South Africa. Development Southern Africa. https://doi.org/10.1080/0376835X.2020.1847636

$\mathrm{Pu}$, B., Teah, M., \& Phau, I. (2019). Hot chili peppers, tears and sweat: How experiencing Sichuan cuisine will influence intention to visit city of origin. Sustainability, 11 (13), 3561. https://doi.org/10.3390/su11133561

Richards, G. (2010). Rethinking niche tourism in the network society. In ATLAS (comp.), Mass tourism vs niche tourism: Cyprus 2010 ATLAS conference 3-5 November Limassol - extended abstracts, 79-85, Arnhem, ATLAS.

Richards, G. (2021). Rethinking niche tourism: The example of backpacking. Croatian Regional Development Journal, 2 (1), 1-12.

Rink, B. (2013). Que(e)rying Cape Town: Touring Africa's 'gay capital' with the Pink Map. In J. Sarmento \& E. Brito-Henriques (Eds.), Tourism in the global South: Heritages, identities and development, 65-90, Lisbon, Centre for Geographical Studies, University of Lisbon.

Rink, B. (2020). Cruising nowhere: A South African contribution to cruise tourism. In J.M. Rogerson \& G. Visser (Eds.), New directions in South African tourism geographies, 249-266, Cham, Switzerland, Springer.

Rittichainuwat, B.N. (2018). Special interest tourism. Newcastle Upon Tyne, Cambridge Scholars Publishing.

Robinson, M., \& Novelli, M. (2005). Niche tourism: An introduction. In M. Novelli (Ed.), Niche tourism: Contemporary issues, trends and cases, 1-11, Oxford, Butterworth-Heinemann.

Rodríguez-Gutiérrez, P., Cruz, F.G.S., Gallo, S.M.P., \& López-Guzmán, T. (2020). Gastronomic satisfaction of the tourist: Empirical study in the Creative City of Popayán, Colombia. Journal of Ethnic Foods, 7, 8. https://doi.org/10.1186/s42779-019-0044-0

Rogerson, C.M. (2006). Creative industries and urban tourism: South African perspectives. Urban Forum, 17, 149-166. https://doi.org/10.1007/s12132-006-0003-x

Rogerson, C.M. (2011). Niche tourism policy and planning: The South African experience. Tourism Review International, 15 (1-2), 199211. https://doi.org/10.3727/154427211X13139345020697

Rogerson, C.M. (2014). Reframing place-based economic development in South Africa: The example of local economic development. Bulletin of Geography: Socio-Economic Series, 24, 203-218.

Rogerson, C.M., \& Baum, T. (2020). COVID-19 and African tourism research agendas. Development Southern Africa, 37 (5), $727-741$. https://doi.org/10.1080/0376835X.2020.1818551

Rogerson, C.M., \& Rogerson, J.M. (2019). Emergent planning for South Africa's blue economy: Evidence from coastal and marine tourism. Urbani izziv, 30 (Supplement), 24-36.

Rogerson, C.M., \& Rogerson, J.M. (2020). COVID-19 and tourism spaces of vulnerability in South Africa. African Journal of Hospitality, Tourism and Leisure, 9 (4), 382-401. https://doi.org/10.46222/ajhtl.19770720-26

Rogerson, C.M., \& Rogerson, J.M. (2021a). COVID-19 travel intentions and changing consumer demand: Research review and policy implications for South Africa. African Journal of Hospitality, Tourism and Leisure, 10 (1), 1-21.

Rogerson, C.M., \& Rogerson, J.M. (2021b). African tourism in uncertain times: COVID-19 research progress. GeoJournal of Tourism and Geosites, 35 (2), 338-347. https://doi.org/10.30892/gtg.38403-740

Rogerson, C.M., \& Rogerson, J.M. (2021c). Looking to the past: The geography of tourism in South Africa in the pre-COVID-19 era. In C.M. Rogerson \& J.M. Rogerson (Eds.), Urban tourism in the Global South: South African perspectives, 39-75, Cham, Switzerland, Springer Nature.

Rogerson, C.M., \& Rogerson, J.M. (2021d). Creative networks and the making of Africa's first UNESCO creative city of gastronomy. In C.M. Rogerson \& J.M. Rogerson (Eds.), Urban tourism in the Global South: South African perspectives, 239-266, Cham, Switzerland: Springer Nature.

Rogerson, C.M., \& Rogerson, J.M. (2021e). The other half of urban tourism: Research directions in the global South. In C.M. Rogerson \& J.M. Rogerson (Eds.), Urban tourism in the Global South: South African perspectives, 1-37, Cham, Switzerland, Springer Nature.

Rogerson, J.M. (2021). Tourism business responses to South Africa's COVID-19 state of emergency. GeoJournal of Tourism and Geosites, 35 (2), 338-347. https://doi.org/10.30892/gtg.35211-657

Rogerson, J.M., \& Slater, D. (2014). Urban volunteer tourism: Orphanages in Johannesburg. Urban Forum, 25, $483-499$. https://doi.org/10.1007/s12132-014-9240-6

Rogerson, J.M., \& Visser, G. (2020). Recent trends in South African tourism geographies. In J.M. Rogerson \& G. Visser (Eds.), New directions in South African tourism geographies, 1-13, Cham, Switzerland, Springer.

Rogerson, J.M., \& Wolfaardt, Z. (2015). Wedding tourism in South Africa: An exploratory analysis. African Journal of Hospitality, Tourism and Leisure, 4 (2), 1-13.

Rogerson, J.M., Lekgau, R., Mashapa, M., \& Rogerson, C.M. (2021). Covid-19 and local business responses: Evidence from South Africa's most tourism-dependent locality. African Journal of Hospitality, Tourism and Leisure, 10 (1), 388-405. https://doi.org/10.46222/ajhtl.19770720-107

Saarinen, J., \& Rogerson, J.M. (Eds.) (2021). Tourism, change and the Global South. Abingdon: Routledge.

Saarinen, J., \& Wall-Reinius, S. (Eds.) (2021). Tourism enclaves: Geographies of exclusive spaces in tourism. Abingdon: Routledge.

Samarathunga, W.H.M.S., \& Gamage, D. (2020). Alternative tourism as an alternate to mass tourism during the post-COVID-19 recovery phrase: The case of Sri Lanka. Sage submissions Pre-print https://doi.org/10.31124/advance.12361301.v1 
Sarmento, J. (2010). Fort Jesus: Guiding the past and contesting the present in Kenya. Tourism Geographies, 12 (2), $246-263$. https://doi.org/10.1080/14616681003725185

Schettini, M.G., \& Troncoso, C.A. (2011). Tourism and cultural identity: Promoting Buenos Aires as the cultural capital of Latin America. Catalan Journal of Communication and Cultural Studies, 3 (2), 195-209. https://doi.org/10.1386/cjcs.3.2.195_1

Seok, H., Joo, Y., \& Nam, Y. (2020). An analysis of sustainable tourism value of graffiti tours through social media: Focusing on TripAdvisor reviews of graffiti tours in Bogota, Colombia. Sustainability, 12 (11), 4426. https://doi.org/10.3390/su12114426

Singh, S. (1992). Urban development and tourism: Case of Lucknow, India. Tourism Recreation Research, 17 (2), $71-78$. https://doi.org/10.1080/02508281.1992.11014651

Sivadasan, F. (2017). Bird-watching and wildlife tours: Alternative tourism escalates niche tourism markets? - aptness of Sarawak State, Malaysia. Journal of Tourism, 18 (2), 31-47.

Somnuxpong, S. (2020). Chiang Mai: A creative city using creative tourism management. Journal of Urban Culture Research, 20, 112132. https://doi.org/10.14456/jucr.2020.8

South African Tourism (2021). Tourism sector recovery plan: COVID-19 response. Johannesburg: South African Tourism

Speakman, M. (2019). Dark tourism consumption in Mexico City: A new perspective of the thanatological experience. Journal of Tourism Analysis, 26 (2), 152-168

Steinbrink, M. (2013). Festifavelisation: Mega-events, slums and strategic city staging - the example of Rio de Janeiro. Die Erde, 144 (2), 129-145. https://doi.org/10.12854/erde-144-10

Su, M.M., \& Wall, G. (2015). Community involvement at Great Wall world heritage sites, Bejing, China. Current Issues in Tourism, 18 (2), 137-157. https://doi.org/10.1080/13683500.2013.823917

Timothy, D. (2021). Democratising the cultural past: Western values, the Global South and cross-cultural perspectives in heritage tourism. In J. Saarinen \& J.M. Rogerson (Eds.), Tourism, change and the Global South, 33-47, Abingdon, Routledge.

Trupp, A., \& Sunanata, S. (2017). Gendered practices in urban ethnic tourism in Thailand. Annals of Tourism Research, 64, 76-86. https://doi.org/10.1016/j.annals.2017.02.004

Uansa-ard, S., \& Binprathan, A. (2018). Creating an awareness of halal MICE tourism business in Chiang Mai, Thailand. International Journal of Tourism Policy, 8 (3), 203-213. https://doi.org/10.1504/IJTP.2018.094490

van der Merwe, C.D. (2013). The limits of urban heritage tourism in South Africa: The case of Constitution Hill, Johannesburg. Urban Forum, 24, 573-588. https://doi.org/10.1007/s12132-013-9197-x

van der Merwe, C.D., \& Rogerson, C.M. (2013). Industrial heritage tourism at 'The big hole', Kimberley, South Africa. African Journal for Physical, Health Education, Recreation and Dance, 19 (Supplement 2), 155-171.

van der Merwe, C.D., \& Rogerson, C.M. (2018). The local development challenges of industrial heritage tourism in the developing world: evidence from Cullinan, South Africa. GeoJournal of Tourism and Geosites, 21 (1), 186-199.

Van Wyk-Jacobs, L. (2018). Astro-tourism as a catalyst for rural route development. PhD (Tourism Management) dissertation, University of Pretoria, Pretoria.

Visser, G. (2002). Gay tourism in South Africa: Issues from the Cape Town experience. Urban Forum, 13(1), 85-94.

Visser, G. (2003). Gay men, tourism and urban space: Reflections on Africa's 'gay capital'. Tourism Geographies, 5(2), 168-189. https://doi.org/10.1080/1461668032000068261

Wang, F., Lu, L., Xu, L., Wu, B., \& Wu, Y. (2020). Alike but different: Four ancient capitals in China and their destination images. International Journal of Tourism Cities, 6 (2), 415-429. https://doi.org/10.1108/IJTC-05-2018-0039

Wassler, P., \& Fan, D.X.F. (2021). A tale of four futures: Tourism academia and COVID-19. Tourism Management Perspectives, 38, 100818. https://doi.org/10.1016/j.tmp.2021.100818

Weiler, B., \& Hall, C.M. (1992). Special interest tourism. (Eds.), London, Belhaven Press.

Wonders, N.A., \& Michalowski, R. (2001). Bodies, borders, and sex tourism in a globalized world: A tale of two cities - Amsterdam and Havana. Social Problems, 48 (4), 545-571. https://doi.org/10.1525/sp.2001.48.4.545

Wu, B., Liu, L., Shao, J., \& Morrison, A.M. (2015). The evolution and space patterns of hutongels in Beijing historic districts. Journal of Heritage Tourism, 10 (2), 129-150. https://doi.org/10.1080/1743873X.2014.985225

Yin, N.L. (2014). Decision factors in medical tourism: Evidence from Burmese visitors to a hospital in Bangkok. Journal of Economics and Behavioral Studies, 6 (2), 84-94. https://doi.org/10.22610/jebs.v6i2.472

Zenker, S., \& Kock, F. (2020). The coronavirus pandemic - A critical discussion of a tourism research agenda. Tourism Management, 81, 104164. https://doi.org/10.1016/j.tourman.2020.104164

*** Department of Tourism (2011a). National tourism sector strategy. Pretoria: Department of Tourism.

*** Department of Tourism (2011b). Education exports and educational tourism: Market study. Pretoria: Department of Tourism.

*** Department of Tourism (2011c). Accessible tourism: Market study. Pretoria: Department of Tourism.

*** Department of Tourism (2011d). The national tourism sector strategy: Actions and sub-actions, 2010-2020. Pretoria: Department of Tourism.

*** Department of Tourism (2018). Transformation strategy for the tourism sector. Pretoria: Department of Tourism.

*** DTI (2007). Backpacking and youth travel in South Africa. Pretoria: DTI.

*** DTI (2010a). 2010/11-2012/13 industrial policy action plan. Pretoria: Economic Sectors and Employment Cluster.

*** DTI (2010b). Niche tourism markets: Avitourism in South Africa. Pretoria: DTI.

*** DTI \& Department of Tourism (2010). Niche tourism: A development framework for the South African tourism industry 2011 -2014. Pretoria: DTI \& DoT

*** ECI Africa (2006a). Community/routes tourism sector study: Growth strategy. Report submitted to the Trade and Industry Chamber Fund for Research into Industrial Development Growth and Equity.

*** ECI Africa (2006b). Backpacker tourism sector study. Report submitted to the Trade and Industry Chamber Fund for Research into Industrial Development Growth and Equity.

*** Grant Thornton (2006). Business tourism sector study: International benchmarking and secondary research report. Report submitted to the Trade and Industry Chamber Fund for Research into Industrial Development Growth and Equity. 